\title{
Ignimbrites of basaltic andesite and andesite compositions from Tanna, New Hebrides Arc
}

\author{
Claude Robin ${ }^{1}$, Jean-Philippe Eissen ${ }^{2}$, Michel Monzier ${ }^{1}$ \\ ${ }^{1}$ ORSTOM, UR 1F, BP 76, Port Vila, Vanuatu, and Department of Geology, Mines and Water Resources of Vanuatu, \\ F=29280-Ptouzané,-Fan. \\ ${ }^{2}$ ORSTOM - UR-1F, B.P. 70, F-29280 Plouzané, France
}

Received: February 19, 1993/Accepted October 10, 1993

\begin{abstract}
Tanna island is part of a large volcanic complex mainly subsided below sea-level. On-land, two series of hydroclastic deposits and ignimbrites overlie the subaerial remains of a basal, mainly effusive volcano. The 'Older' Tanna Ignimbrite series (OTI), Late Pliocene or Pleistocene in age, consists of ash flows and ash- and scoria-flow deposits associated with fallout tephra layers, overlain by indurated pumice-flow deposits. Phreatomagmatic features are a constant characteristic of these tuffs. The 'younger' Late Pleistocene pyroclastics, the Siwi sequence, show basal phreatomagmatic deposits overlain by two successive flow units, each comprising a densely welded layer and a nonwelded ash-flow deposit. Whole-rock analyses of 17 juvenile clasts from the two sequences (vitric blocks from the phreatomagmatic deposits, welded blocks, scoriaceous bombs and pumices from the ignimbrites) show basaltic andesite and andesite compositions $\left(\mathrm{SiO}_{2}=53-60 \%\right)$. In addition, 296 microprobe analyses of glasses in these clasts show a wide compositional range from 51 to $69 \% \mathrm{SiO}_{2}$. Dominant compositions at $\sim 54,56,58.5$ and $61-62 \% \mathrm{SiO}_{2}$ characterize the glass from the OTI. Glass compositions in the lower phreatomagmatic - deposits from the Siwi sequence also show multimodal distribution, with peaks at $\mathrm{SiO}_{2}=55,57.5,61-62$ and $64 \%$ whereas the upper ignimbrite has a predominant composition at $61-62 \%$ $\mathrm{SiO}_{2}$. In both cases, mineralogical data and crystal fractionation models suggest that these compositions represent the magmatic signature of a voluminous layered chamber, the compositional gradient of which is the result of fractional crystallization. During two major eruptive stages, probably related to two caldera collapses, the OTI and Siwi ignimbrites represent large outpourings from these magmatic reservoirs. The successive eruptive dynamics, from phreatomagmatic to Plinian, emphasize the role of water in initiating the eruptions, without which the mafic and intermediate magmas probably would not have erupted.
\end{abstract}

Correspondence to: Claude Robin
Key words: Island arc volcanism - New Hebrides - Ignimbrite - Phreatomagmatic deposits - Basaltic andesite - Glass composition - Crystal fractionation

\section{Introduction}

Ignimbrites are welded or nonwelded deposits of pyroclastic flows (Sparks et al. 1973; Williams and McBirney 1979), and most ignimbrite deposits result from ash flows and pumice flows of gas-rich, evolved material. Voluminous ignimbrites related to shallow dacitic or rhyolitic magma reservoirs are likely to occur either in large explosive volcanoes, during the caldera stage, or in large continental calderas where they represent the climactic eruptive stage. Less acid (andesitic) pyroclastic flows are also a common feature of andesitic volcanoes, but these generally involve smaller volumes of magma. Ash-flow deposits of large volume and basaltic or basaltic andesite composition are scarce, and there are few published studies documenting pyroclastic eruptions that imply mafic ignimbrites. The only well-known examples are Masaya in Nicaragua, Tambora in Indonesia, and Ambrym in the New Hebrides Arc. At Masaya, caldera collapse apparently formed in response to large-scale eruptions of basaltic magma, including ignimbrites and surges (Williams 1983; Bice 1985). At Tambora, at least seven pyroclastic flows and large amounts of fall deposits with a trachyandesite composition (54-58\% $\mathrm{SiO}_{2}$ ) were generated during the climactic stage of the eruption (Sigurdsson and Carey 1989). At Ambrym, basaltic ash flows occurred in the late eruptive stages of a voluminous pyroclastic series, the eruption of which led to the caldera collapse (Monzier et al. 1991; Robin et al. 1993). In addition, Taylor (1956) and Williams and Curtis (1964) reported ignimbrites (in other volcanoes from South West Pacific, precisely) that may range from rhyolitic to basaltic in composition.

The development of the Tanna volcanic complex in the New Hebrides volcanic arc shows the eruption of 
two major pyroclastic sequences, including thick welded and nonwelded ignimbrites closely associated with typical phreatomagmatic deposits. The vitric components of these rocks range compositionally from basalt/basaltic andesite to dacite/rhyolite. This paper is devoted to: (1) a brief description of the volcanologic characteristics and extent of these deposits; (2) a discussion of their petrologic significance based on a more detailed petrological description and analyses of the juvenile clasts; and (3) discussion of the eruptive mechanisms, with the aim of proposing a model of eruption.

\section{Structure of the Tanna volcanic complex}

Tanna $\left(19^{\circ} 30^{\prime} \mathrm{S}-169^{\circ} 20^{\prime} \mathrm{E} ; 561 \mathrm{~km}^{2}\right)$ is the main island in the southern Vanuatu Archipelago, rising to $1084 \mathrm{~m}$ elevation at Mount Tukosmeru (Fig. 1). Present volcanic activity is restricted to the small Yasur scoria cone ( $350 \mathrm{~m}$ high) in the southern part of the island. Carney and McFarlane (1979) divided Tanna's volcanics into three groups of lavas and pyroclastics: two ancient groups of Late Pliocene and Pleistocene age, the Green Hill and Tukosmeru Groups, from the names of two volcanic centres in the north and south of the island, and the younger Late Pleistocene to Holocene Siwi Group (Fig. 1a). The latter includes the presently active Yasur cone, the volcanics from Ombus, another scoria cone recently extinct, and the Yenkahe volcanics which comprise a remarkable ignimbrite sheet, the Siwi ignimbrite (Nairn et al. 1988).

\section{The Eastern Tanna Volcano (ETV) and the Old Tanna Ignimbrites (OTI)}

Carney and McFarlane (1979) recognized two volcanic centres in the former Green Hill Group, respectively the Green Hill centre in the north and the WaesisiLowniel centre in the south, near the eastern coast. They also included in this Group the thick pyroclastic deposits which lie between these two centres along the eastern coast, but were uncertain of their origin. We observed and sampled these deposits at sites 16, 22 and 23 (Fig. 1a). According to Carney and McFarlane's observations, regional eastward dips suggest an origin in the west, but there is no morphological evidence to support a volcanic edifice in the central area of the island. As suggested by these authors, an eastward increase in grain size of the pyroclastics would represent

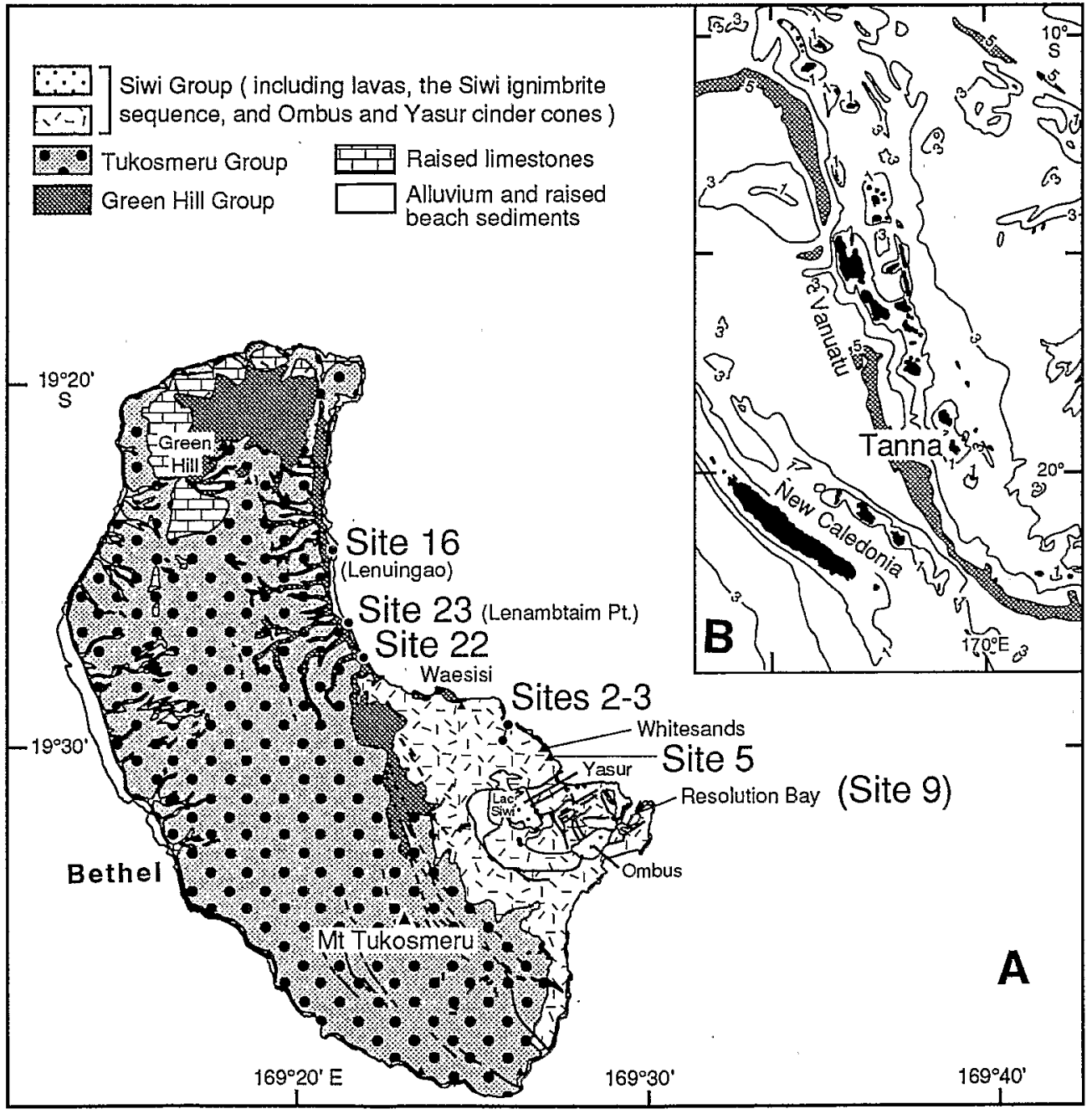

Fig. 1. A Geological sketch map of Tanna island, from Carney and McFarlane (1979), showing the main units and location of studied outcrops. B Location of Tanna island in the New Hebrides Arc. Dotted area: New Hebrides Trench. Bathymetry in kilometres 


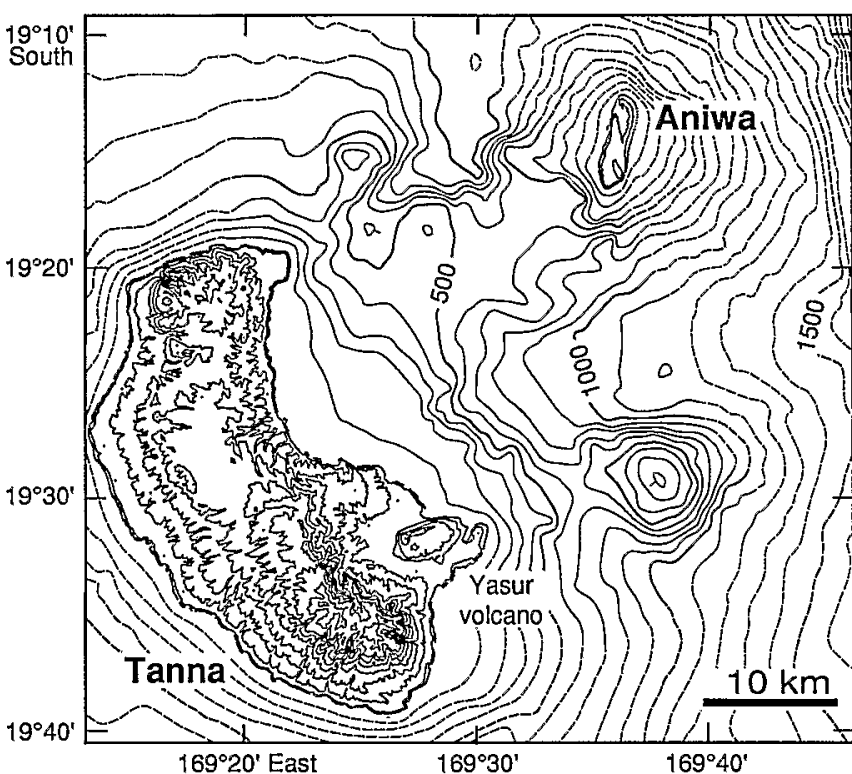

Fig. 2. Bathymetric data obtained during the ORSTOM Calis Cruise, May 1991 northeast of Tanna island. Topographic and bathymetric interval contour: $100 \mathrm{~m}$

a lateral transition to coarser deposits closer to a centre located in the east, and the observed regional dip may not be primary.

Bathymetric data obtained during a recent marine survey (ORSTOM Calis Cruise, May 1991) revealed that the crescent-shaped island belongs to a Plio-Pleistocene volcanic complex, about $40 \mathrm{~km}$ wide and some $1800 \mathrm{~m}$ high, relative to the arc basement (Fig. 2). Onland, field observations show that part of the volcanic series assigned to the Green Hill and Tukosmeru Groups, especially the lava flows and pyroclastics exposed along the eastern coast at sites 16, 22 and 23, and in the central part of the island (under subsequent pyroclastics and raised limestones) form the western slope of a large edifice. This edifice, now collapsed below sea-level, we name the Eastern.Tanna Volcano (ETV). A pile of lava flows and intercalated agglomerates, forming the 100-150-m-high coastal cliff near Waesisi, represent the remains from the southwest flank of this cone. Thick massive to lenticular units of coarse scoria and breccia, numerous dykes intruding scoria and lavas, and the general dips of these lavas, suggest that the vent was located not far away to the northeast, probably near $19^{\circ} 26^{\prime} \mathrm{S}$ and $169^{\circ} 25^{\prime} \mathrm{E}$.

At sites 16, 22 and 23, a complex pyroclastic series overlies the lavas from ETV (Fig. 3). In this paper, this series is named the Old Tanna Ignimbrites (OTI) to distinguish them from the Late Pleistocene Siwi ignimbrite. Similarly to the associated lavas, local dips (WSW at sites 22-23, and W-NW at site 16) and their distribution along the coast suggest that the source of these pyroclastics is the ETV.

\section{Volcanic centres}

Thus, at least four main volcanic units compose the Tanna volcanic complex: (1) the Green Hill centre in the north; (2) the Tukosmeru centre in the southwest; (3) Late Pleistocene Yenkahe volcanics in the southeast; and (4) the Eastern Tanna Volcano, in a more central position, but now collapsed below sea-level and dissected by conjugate NW-SE and SW-NE faults, as suggested by the bathymetry (Fig. 2). Scarce ages do not allow a useful geochronology at present: three radiometric dates from Green Hill, Tukosmeru and Yenkahe volcanics give ages of $2.45,0.65$ and $0.23 \mathrm{Ma}$ respectively (Dugas et al. 1976; Carney and McFarlane 1979). Since the OTI (that lie on the Green Hill volcanics) have their source in the east, Eastern Tanna Volcano was probably as volumetrically large as $\mathrm{Tu}-$ kosmeru volcano, although confirmation is still required. In such a case, the Green Hill centre in the north and Ombus and Yasur cones in the south would appear as subordinate volcanic centres.

\section{Volcanological features of the OTI and Siwi pyroclastics}

\section{The $O T I$ at sites 16,22 and 23}

The OTI crop out along gullies perpendicular to the coast, carved into the flanks up to $5 \mathrm{~km}$ inland. Good exposures are generally confined to discontinuous coastal cliffs. Sections observed at sites 16-22-23 (Fig. 3) allow us to divide this series into three parts:

1. A lower part that consists of brown to yellowish ashflow deposits and bedded tuffs that show alternating thin and coarse ash including centimetre-sized quenched glass fragments, pumice and lithics (layers 2 and 3, Fig. 3). Commonly, these deposits have a clayey and sometimes palagonitized matrix. They reach $9 \mathrm{~m}$ in thickness at site 16 where they are overlain by a $5-\mathrm{m}$ thick ash and scoria deposit of the intermediate part of the section (layer 4). At site 22, only the upper $3 \mathrm{~m}$ of this lower sequence (ash-flow-bearing quenched vitric clasts, layer 3) are observed. Here, no sharp discontinuity is present and the ash-flow deposits grade into the intermediate pyroclastic flow deposits.

2. The intermediate pyroclastic flow deposits (layer 4), enriched in scoria and bombs, occur at all three sites. At site 22, transverse sections to the west-directed flows show lenses (up to $6 \mathrm{~m}$ thick and a few tens of metres long) mantled by a 6-m-thick succession of fallout ash and lapilli scoria layers (about 30 layers, 5-60 $\mathrm{cm}$ thick; 6 , site 22). The lenses comprise unsorted massive beds of coarse ash, 2-3 m thick, bearing dense and pumice lapilli, scoria and small cauliflower bombs that may form up to $60 \%$ of the volume. These deposits locally develop slightly wavy bedded structures some metres long, indicating deposition from pyroclastic surges. The dense lapilli, up to $2 \mathrm{~cm}$ in size, are commonly quenched vitric clasts (from disaggregated bombs following thermal cracking). Accidental clasts are rare (about $2 \%$ ).

3. At Lenambtaim Point (site 23), three indurated pumice flow units were emplaced almost simultaneously, forming a single cooling unit. They represent the major 


\section{OTI IGNIMBRITE SEQUENCE}

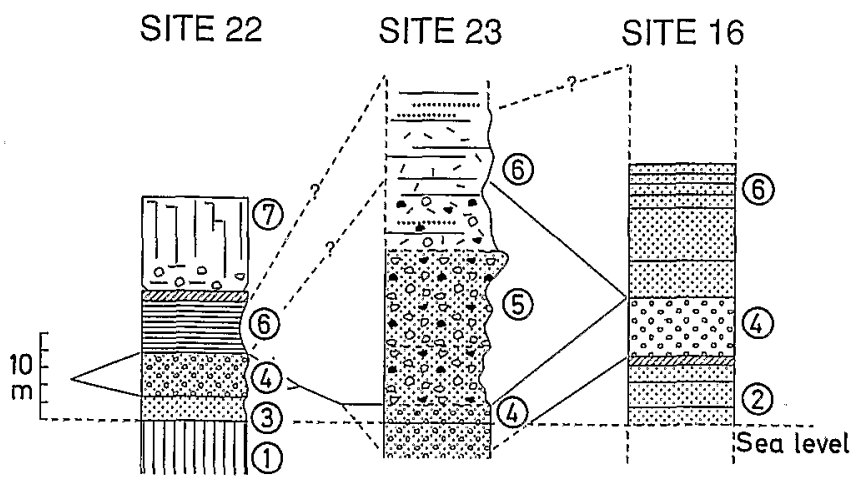

SIWI IGNIMBRITE SEQUENCE

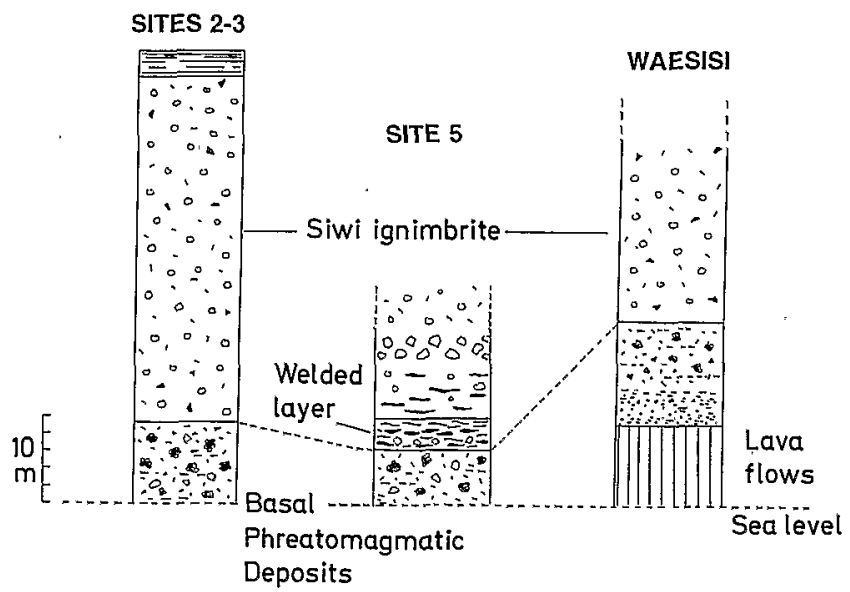

Fig. 3. Synthetic sections of OTI and Siwi ignimbrite sequences. Location of sites in Fig. 1. OTI sequence: 1, lava flows; 2 and 3, phreatomagmatic ashy deposits bearing vitric clasts; 4 , ash- and scoria-flow deposits bearing cauliflower bombs, juvenile vitric clasts and accidental clasts; 5 , main ignimbritic deposits of the OTI; 6, ash and lappilli fallout layers; 7, lava flow. Siwi sequence: at site 2, recent fallout ash and lapilli layers from Yasur overlie the ignimbrite sequence

flows of the OTI (layer 5 on Fig. 3; field exposure Fig. 4). Along the coast, they form a 30-50-m-high cliff and dip slightly to the S-SW. No evidence of erosion or intercalated buried soil has been observed between these flow units. These tuffs include $30-40 \%$ of slightly porphyritic glassy collapsed pumice blocks and bombs, mainly poorly vesicular and glassy blocks, generally $10-25 \mathrm{~cm}$ across, but up to $1 \mathrm{~m}$. Some of the dense fragments are elongate and ribboned lenses $5-10 \mathrm{~cm}$ thick and $20-80 \mathrm{~cm}$ long, made of compacted scoria and pumice lapilli (analyses in Table 1). Over the whole outcrop, the blocks are distributed at random; nevertheless, concentrations of dark, smaller dense vitric clasts or discontinuous trains of large fragments show incipient grading by zones. Xenoliths are represented by limestone, lavas from the basement and blocks of a plagioclase-rich andesite.

At the three sites, the upper part of deposits consists of bedded fallout tephra (6, Fig. 3), and at site 22 , a lava flow overlies the pyroclastic sequence. In the sections exposed upstream in the Lenuai river, Carney and McFarlane (1979) report that these pumice lapilli tuffs have smaller bombs and more angular glass fragments than along the coast. As at site 22, well-bedded horizons of fallout tephra are associated with the pyroclastic flow deposits and a basaltic andesite flow overlies the pyroclastic sequence. Total thickness may reach about $80 \mathrm{~m}$. We recognized the OTI up to the western coast; their thickness is at least $15 \mathrm{~m}$ in the region of Bethel where they are well exposed, underlying recent raised limestones.

\section{The Siwi ignimbrite sequence}

Nairn et al. (1988) investigated the Upper Pleistocene volcanics and emphasized the presence of the Siwi ignimbrite which covers a large area in the southeast part of the island. These authors attribute to this ignimbrite an approximative age of a few tens of thousands of years and relate the pyroclastic event to the collapse area in which the Ombus and Yasur cones are located. The deposits were observed along the coast at Waesisi and at sites 2, 3, 5, and in the region of Resolution Bay (Fig. 1a). The intimate association between ash-flow deposits and thick underlying phreatomagmatic deposits led us to reconsider the Siwi ignimbrite as part of a complex sequence including these phreatomagmatic deposits.

At sites 3 and 5 (Figs. 1,3), the lower deposits of the Siwi sequence are agglomerates of light-brown coarsegrained ash, bearing vitric fragments $2-3 \mathrm{~mm}$ to $2 \mathrm{~cm}$ across, $25 \%$ dense vitric bombs (up to $60 \mathrm{~cm}$ ) and scoria $(2-3 \mathrm{~mm}$ to $20 \mathrm{~cm}$ ) and $10 \%$ accidental clasts. Locally, more finely grained surge deposits occur. The lower half (about $3 \mathrm{~m}$ ) of these typical phreatomagmatic deposits is indurated. In the upper part of the deposit, bombs become more abundant and interfingering between these deposits and the following ignimbrite sheet can be seen.

The succeeding layer is a 4-8-m-thick densely welded layer (layer 2 at site 5, Fig. 3). The top of this welded tuff grades into the base of the nonwelded flow, which is, over a few metres' thickness, rich in poorly vesicular glassy lenses showing breadcrusts. These latter become less abundant and then disappear from the pumice deposit. In places, a 2-3-m-thick block-rich layer separates the lower part of the pumice flow from the rest of the flow, about $30 \mathrm{~m}$ thick, which becomes homogeneous. In the latter, the pumices (generally centimetre sized, but up to $15 \mathrm{~cm}$ across) and the ash are in equal volume. Accidental clasts do not exceed $2 \%$. To the south of site 5 , near the caldera rim, the Siwi ignimbrite consists of two successive flow units, each showing a basal welded layer, $2-5 \mathrm{~m}$ thick.

\section{Petrology of juvenile clasts}

\section{Sampling and analytical techniques}

Seventeen juvenile clasts (vitric blocks, scoria and pumices) from the OTI and Siwi sequences have been 


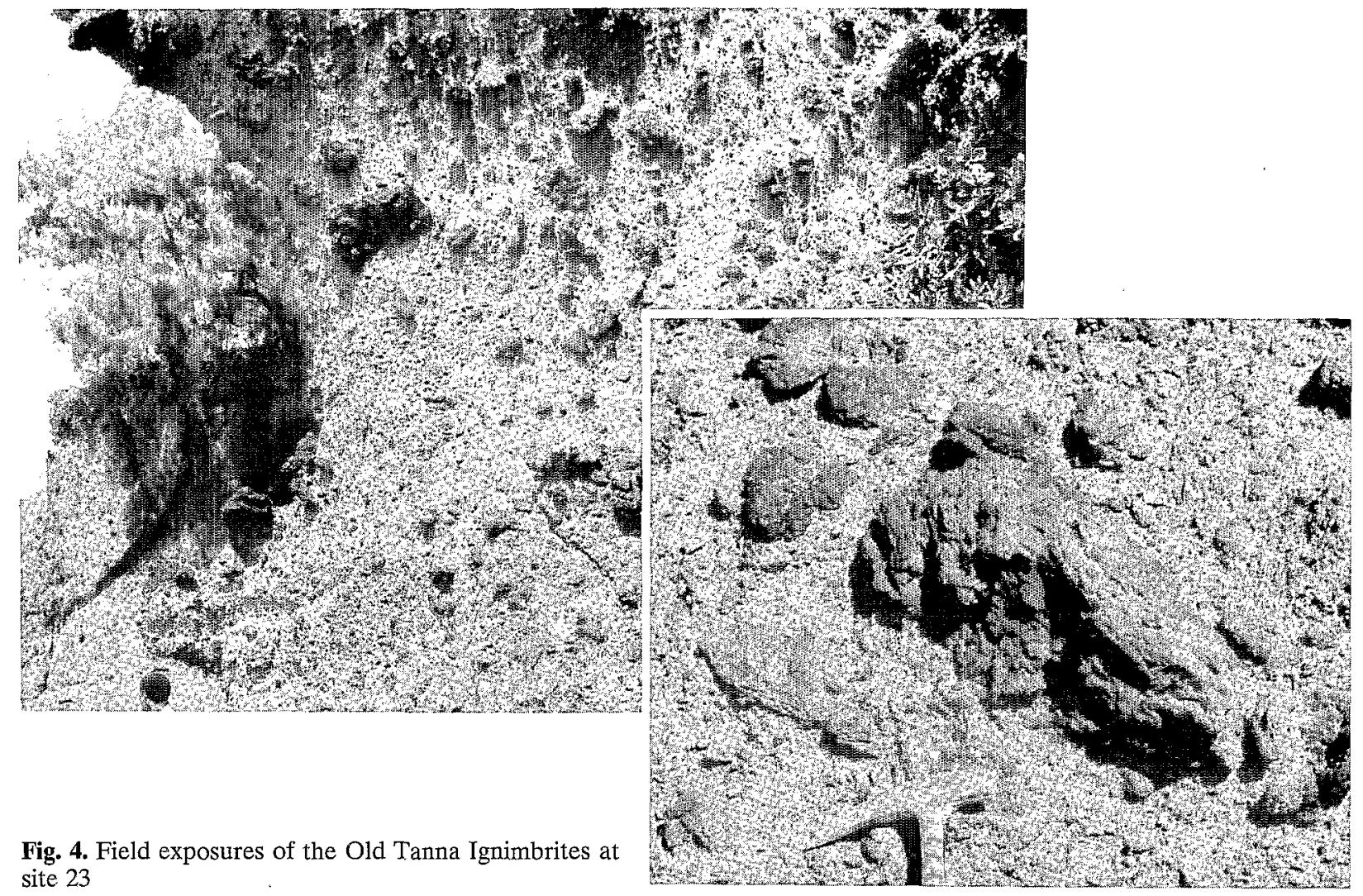

analysed. Their whole-rock compositions (Table 1) plus 295 microprobe analyses of minerals and 296 analyses of glass from 11 thin sections form the petrological data on which our discussion and interpretation are based. Whole-rock analyses have been obtained at the Université de Bretagne Occidentale in brest.

Selected fragments were ground in agate. Powders were digested with a concentrated acid mixture $(1: 8$ $\mathrm{HNO}_{3}-\mathrm{HF}$ ). Fluorides were then dissolved and $\mathrm{HF}$ neutralized with an $\mathrm{H}_{3} \mathrm{BO}_{3}$ solution. International standards (JB2, BEN, ACE, GSN, MICA-Fe) were used for calibration. $\mathrm{Rb}$ determination was performed by flame Atomic Emission Spectrometry. All other elements were determined by Inductively Coupled Plasma Emission Spectrometry. Relative standard deviation for major oxides: $\mathrm{SiO}_{2}=3 \%, \quad \mathrm{TiO}_{2}=3 \%$, $\mathrm{Al}_{2} \mathrm{O}_{3}=2 \%, \quad \mathrm{Fe}_{2} \mathrm{O}_{3}=2 \%, \quad \mathrm{MnO}=5 \%, \quad \mathrm{MgO}=2 \%$, $\mathrm{CaO}=2 \%, \mathrm{Na}_{2} \mathrm{O}=2 \%, \mathrm{~K}_{2} \mathrm{O}=3 \%, \mathrm{P}_{2} \mathrm{O}_{5}=4 \%$. Limit of detection and relative standard deviation for trace elements: $\mathrm{Rb}=1 \mathrm{ppm}, 5 \% ; \mathrm{Sr}=0.2 \mathrm{ppm}, 5 \% ; \mathrm{Sc}=0.25$ ppm, $5 \% ; \mathrm{V}=2 \mathrm{ppm}, 5 \% ; \mathrm{Cr}=1 \mathrm{ppm}, 5 \% ; \mathrm{Co}=1 \mathrm{ppm}$, 5 to $10 \% ; \mathrm{Ni}=2 \mathrm{ppm}, 5 \% ; \mathrm{Zr}=1 \mathrm{ppm}, 5 \% ; \mathrm{Nb}=0.8$ ppm, 5-10\%; Y $=0.5 \mathrm{ppm}, 5 \%$; La $=0.8 \mathrm{ppm}, 5 \%$; $\mathrm{Nd}=2 \mathrm{ppm}, 10 \% ; \mathrm{Eu}=0.2 \mathrm{ppm}, 5-10 \% ; \mathrm{Dy}=0.4 \mathrm{ppm}$, $5 \% ; \mathrm{Er}=0.8 \mathrm{ppm}, 10 \% ; \mathrm{Yb}=0.2 \mathrm{ppm}, 5 \%$.

Mineral and glass compositions were determined with the CAMECA automatized microprobe at the Centre Régional de Mesures Physiques (ClermontFerrand University), using mineral standards supplied by the BRGM (Orleans). Operating conditions: $15 \mathrm{KV}$ accelerating potential, $10 \mathrm{MA}$ beam intensity and $10 \mathrm{~s}$ count time.

\section{Old Tana Ignimbrites}

Most glassy blocks and pumices are aphyric or poorly porphyritic (generally $2-4 \%$ phenocrysts; $6 \%$ maximum). The juvenile blocks show eutaxitic textures with banded and welded matrix, and flattened glassy shards. The bulk compositions of nine samples from sites 16 , 22 and 23 range from 53.3 to $58.8 \% \mathrm{SiO}_{2}$ (Table 1 ). These samples follow the high-K arc differentiation trend previously recognized at Tanna (Williams and Warden 1964; Gorton 1977; Coulon and Maury 1981) (Fig. 5). Juvenile clasts in lower and intermediate OTI deposits (layers 2, 3, 4, Fig. 3) show a wide range in plagioclase composition (An 90-58; Fig. 6a, b) whereas plagioclase from the upper pyroclastic flows at Lenambtaim Point (layer 5) shows a more felsic composition and a narrow range (An 58-42; Fig. 6c). These data are consistent with the compositional evolution of clinopyroxene toward the Fe pole from the basal deposits to the upper layers, also marked by an evolution of the $\mathrm{Mg}$ number from 49 to 36 . Fe-Ti oxides are titanomagnetites (9-13\% $\mathrm{TiO}_{2}$ ). Low Ca-pyroxene has been only observed in dense vitric lapilli from lower andesitic ash-flow deposits (layer 2, Fig. 3; sample TA 15 , Table 1), at site 16 . Olivine (Fo 60) is scarce.

Some 144 microprobe analyses of glassy shards and welded laminations from the OTI vary from 54 to $69 \%$ $\mathrm{SiO}_{2}$ (Figs. 7, 8), with two main peaks and 56-57\% $\mathrm{SiO}_{2}$ and $60-61 \% \mathrm{SiO}_{2}$, and minor peaks at 54-55, 59, 61-62 and $69 \% \mathrm{SiO}_{2}$ (Fig. 9). Average compositions of these peaks are reported in Table 2 . It is worth noting that the wole range of compositions may be repre- 
Table 1. Whole-rock analyses of juvenile clasts

\begin{tabular}{|c|c|c|c|c|c|c|c|c|c|c|c|c|c|c|c|c|c|}
\hline \multirow[t]{3}{*}{ Sample } & \multicolumn{7}{|c|}{ Siwi ignimbrite } & \multicolumn{10}{|c|}{ OTI sequence } \\
\hline & \multicolumn{5}{|c|}{ Sites $2-3-5$} & \multirow{2}{*}{$\begin{array}{l}\text { Site } 9 \\
\text { TA 9B }\end{array}$} & \multirow{2}{*}{$\begin{array}{l}\text { Site } 10 \\
\text { TA } 10 \mathrm{~B}\end{array}$} & \multicolumn{2}{|l|}{ Site 16} & \multicolumn{4}{|l|}{ Site 22} & \multicolumn{2}{|l|}{ Site 23} & \multirow[b]{2}{*}{ TA 23C } & \multirow[b]{2}{*}{ TA $23 \mathrm{G}$} \\
\hline & TA 2B & TA 3B & TA 5A & TA 5B & TA 5C & & & TA 15 & TA 16 & TA $22 \mathrm{~A}$ & TA 22B & TA $22 \mathrm{C}$ & TA 22D & TA 23A & TA 23B & & \\
\hline $\mathrm{SiO}_{2}$ & 60.00 & 59.80 & 59.40 & 58.65 & 56.30 & 59.20 & 53.70 & 59.30 & 57.30 & 55.20 & 58.80 & 57.30 & 54.55 & 53.30 & 58.60 & 55.80 & 57.00 \\
\hline $\mathrm{TiO}_{2}$ & 0.89 & 0.77 & 0.89 & 0.88 & 0.76 & 0.88 & 0.70 & 0.69 & 0.78 & 0.89 & 0.81 & 0.81 & 0.74 & 0.79 & 0.79 & 0.78 & 0.80 \\
\hline $\mathrm{Al}_{2} \mathrm{O}_{3}$ & 15.33 & 15.57 & 15.12 & 14.93 & 17.56 & 15.19 & 17.45 & 16.68 & 16.18 & 16.03 & 15.98 & 16.41 & 16.33 & 16.68 & 15.87 & 15.92 & 15.69 \\
\hline $\mathrm{Fe}_{2} \mathrm{O}_{3}$ & 8.60 & 7.99 & 8.65 & 8.77 & 9.16 & 8.57 & 9.66 & 7.68 & 9.15 & 10.83 & 8.51 & 8.87 & 9.23 & 10.36 & 8.91 & 9.91 & 9.43 \\
\hline $\mathrm{MnO}$ & 0.20 & 0.19 & 0.19 & 0.19 & 0.23 & 0.19 & 0.17 & 0.18 & 0.16 & 0.20 & 0.17 & 0.17 & 0.17 & 0.21 & 0.19 & 0.19 & 0.18 \\
\hline $\mathrm{MgO}$ & 1.92 & 2.04 & 1.97 & 2.02 & 3.07 & 1.89 & 3.87 & 1.99 & 2.61 & 3.70 & 2.38 & 2.89 & 4.05 & 3.80 & 2.58 & 3.49 & 3.15 \\
\hline $\mathrm{CaO}$ & 4.50 & 4.80 & 4.56 & 4.71 & 6.65 & 4.41 & 8.94 & 5.68 & 6.00 & 7.77 & 5.66 & 6.48 & 7.51 & 7.82 & 5.84 & 7.43 & 6.52 \\
\hline $\mathrm{Na}_{2} \mathrm{O}$ & 4.10 & 4.30 & 4.36 & 4.20 & 4.35 & 4.25 & 3.31 & 4.13 & 4.08 & 3.32 & 4.05 & 3.81 & 3.18 & 3.24 & 4.13 & 3.65 & 3.72 \\
\hline $\mathrm{K}_{2} \mathrm{O}$ & 3.93 & 3.20 & 4.00 & 3.80 & 1.90 & 3.96 & 1.83 & 2.10 & 2.74 & 2.09 & 3.13 & 2.80 & 2.21 & 1.90 & 2.93 & 2.32 & 2.59 \\
\hline $\mathrm{P}_{2} \mathrm{O}_{5}$ & 0.69 & 0.50 & 0.67 & 0.65 & 0.47 & 0.67 & 0.33 & 0.32 & 0.42 & 0.35 & 0.52 & 0.47 & 0.39 & 0.42 & 0.46 & 0.38 & 0.43 \\
\hline \multirow[t]{2}{*}{ LOI } & -0.01 & 0.18 & 0.22 & 0.60 & 0.19 & 0.28 & 0.23 & 0.88 & 0.53 & -0.17 & -0.19 & 0.02 & 1.01 & 1.60 & -0.16 & 0.39 & -0.02 \\
\hline & 100.15 & 99.34 & 100.03 & 99.40 & 100.64 & 99.49 & 100.19 & 99.63 & 99.95 & 100.21 & 99.82 & 100.03 & 99.37 & 100.12 & 100.14 & 100.26 & 99.49 \\
\hline $\mathrm{Rb}$ & 59 & 47 & 58 & 56 & 31 & 59 & 26 & 30 & 38 & 32 & 48 & 42 & 34 & 29 & 44 & 46 & 39 \\
\hline $\mathrm{Ba}$ & 745 & 765 & 740 & 722 & 580 & 1445 & 432 & 248 & 1140 & 436 & 600 & 545 & 453 & 422 & 577 & 454 & 524 \\
\hline $\mathrm{Nb}$ & 1.60 & 1.50 & 2.00 & 1.50 & 1.35 & 1.90 & 1.00 & 1.35 & 1.05 & 0.90 & 1.50 & 1.50 & 0.90 & 1.00 & 1.40 & 0.60 & 1.60 \\
\hline $\mathrm{La}$ & 21.50 & 15.25 & 19.25 & 18.40 & 15.25 & 18.80 & 9.00 & 9.50 & 13.50 & 10.00 & 14.80 & 13.40 & 11.20 & 9.80 & 13.60 & 10.80 & 12.40 \\
\hline $\mathrm{Sr}$ & 445 & 476 & 440 & 443 & 547 & 438 & 647 & 468 & 537 & 495 & 536 & 583 & 580 & 567 & 530 & 567 & 548 \\
\hline Nd & 29.0 & 23.0 & 28.0 & 29.0 & 21.0 & 28.0 & 12.5 & 15.5 & 19.5 & 16.0 & 24.0 & 21.0 & 18.0 & 17.0 & 21.0 & 19.0 & 20.0 \\
\hline $\mathrm{Zr}$ & 144 & 122 & 151 & 141 & 101 & 148 & 65 & 78 & 99 & 89 & 118 & 105 & 88 & 81 & 110 & 84 & 99 \\
\hline $\mathrm{Eu}$ & 1.75 & 1.55 & 1.70 & 1.70 & 1.45 & 1.85 & 1.05 & 1.15 & 1.55 & 1.10 & 1.60 & 1.50 & 1.30 & 1.25 & 1.40 & 1.30 & 1.25 \\
\hline Dy & -5.9 & 5.1 & 5.8 & 5.7 & 4.4 & 5.8 & 3.5 & 4.6 & 4.3 & 4.2 & 4.9 & 4.3 & 3.9 & 3.7 & 4.6 & 4.3 & 4.5 \\
\hline $\mathrm{Y}$ & 35.0 & 30.5 & 36.0 & 35.0 & 27.0 & 36.0 & 20.0 & 28.0 & 26.8 & 29.0 & 31.0 & 29.0 & 24.0 & 23.0 & 29.0 & 25.0 & 27.0 \\
\hline Er & 3.6 & 3.1 & 3.7 & 3.7 & 3.0 & 3.6 & 2.2 & 2.7 & 2.6 & 3.0 & 3.0 & 2.7 & 2.5 & 2.1 & 3.2 & 2.0 & 2.4 \\
\hline $\mathrm{Yb}$ & 3.40 & 3.05 & 3.50 & 3.35 & 2.65 & 3.40 & 2.00 & 2.65 & 2.58 & 2.65 & 2.93 & 2.60 & 2.23 & 2.30 & 2.85 & 2.35 & 2.58 \\
\hline $\mathrm{V}$ & 175 & 157 & 177 & 179 & 238 & 168 & 281 & 130 & 238 & 330 & 198 & 237 & 246 & 320 & 222 & 296 & 258 \\
\hline $\mathrm{Cr}$ & .4 .5 & 4.5 & 2.5 & 4.0 & 22.0 & 10.0 & 22.5 & 43.0 & 3.3 & 20.0 & 15.0 & 26.0 & 90.0 & 37.0 & 12.0 & 17.0 & 21.0 \\
\hline Co & 17.0 & 17.0 & 16.5 & 17.0 & 21.0 & 16.0 & 27.0 & 16.0 & 20.0 & 26.0 & 19.0 & 21.0 & 26.0 & 28.0 & 20.0 & 25.0 & 23.0 \\
\hline $\mathrm{Ni}$ & 6.5 & 6.0 & 3.5 & 6.0 & 16.0 & 7.0 & 20.0 & 22.0 & 9.0 & 26.0 & 11.0 & 16.0 & 47.0 & 24.0 & 10.0 & 18.0 & 17.0 \\
\hline $\mathrm{Sc}$ & 15.0 & 16.0 & 14.5 & 15.0 & 18.0 & 15.0 & 23.0 & 17.7 & 19.0 & 26.0 & 17.0 & 19.0 & 22.0 & 26.0 & 19.0 & 23.0 & 21.0 \\
\hline $\mathrm{Mg} \#$ & 0.33 & 0.36 & 0.33 & 0.34 & 0.42 & 0.33 & 0.47 & 0.36 & 0.39 & 0.43 & 0.38 & 0.42 & 0.49 & 0.45 & 0.39 & 0.44 & 0.42 \\
\hline & Nig \# & & $f=$ & & 120 & & & & & & & & & & & & \\
\hline
\end{tabular}




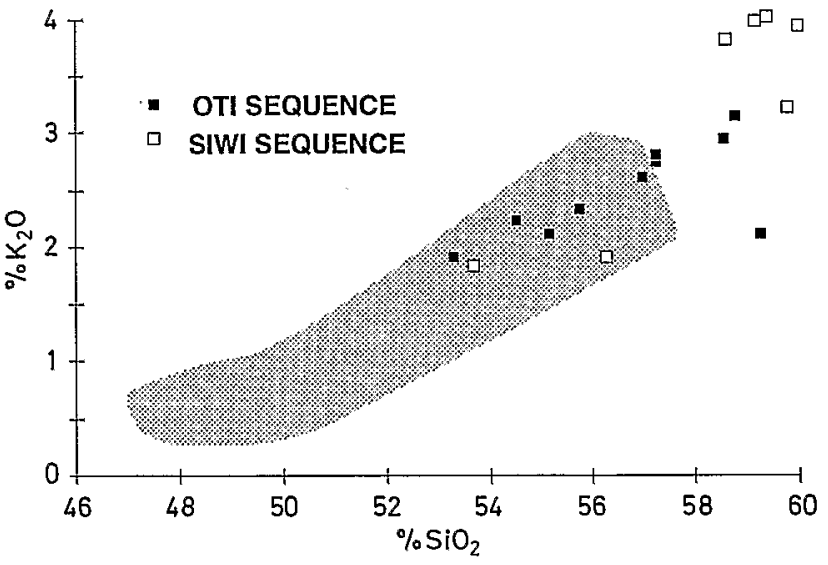

Fig. 5. $\mathrm{K}_{2} \mathrm{O}-\mathrm{SiO}_{2}$ diagram showing the OTI and Siwi whole-rock analyses from Table 1 . The dotted zone represents the area covered by lavas (from Williams and Warden 1964; Gorton 1977; Coulon and Maury 1981 and our unpublished analyses)

sented within one flow deposit of the upper sequence (site 23, Fig. 8) or even by only one sample (welded tuff showing eutaxitic texture) from this flow deposit (sample $23 \mathrm{C}$ as an example, Figs. 8, 9).

\section{Siwi Ignimbrite}

Seven whole-rock analyses of juvenile clasts from the three facies of the Siwi sequence - the lower phreatomagmatic deposits, the intermediate densely welded tuff and the upper nonwelded tuff - are given in Table 1. Three samples from the basal layer include a basaltic andesite and two andesites, whereas the upper ignimbrite is mainly andesite $\left(\mathrm{SiO}_{2}=59-60 \%\right)$.

Some 152 analyses of glass from six samples range from 51 to $65.5 \% \mathrm{SiO}_{2}$ (Fig. 7). The lower phreatomagmatic deposits show a multimodal distribution, with three main peaks at $\mathrm{SiO}_{2}=54-55,57-58$ and $61-62 \%$ $\mathrm{SiO}_{2}$, and also a minor dacite peak at $64 \% \mathrm{SiO}_{2}$ (Fig. $9)$. In contrast, the welded layer, as well as juvenile clasts from the upper nonwelded ash-flow deposit, are characterized by a unimodal compositional distribution of the glass, at $61-62 \% \mathrm{SiO}_{2}$ (Fig. 9).

Such variations in the vitric phase are matched by the mineralogical data. A wide range of plagioclase composition (An 92-40, Fig. 6d) and olivine (Fo 5672) may be observed in the lower deposits whereas more narrow ranges for these phases occur in the upper ash-flow deposit (plagioclase: An 56-43 with a few
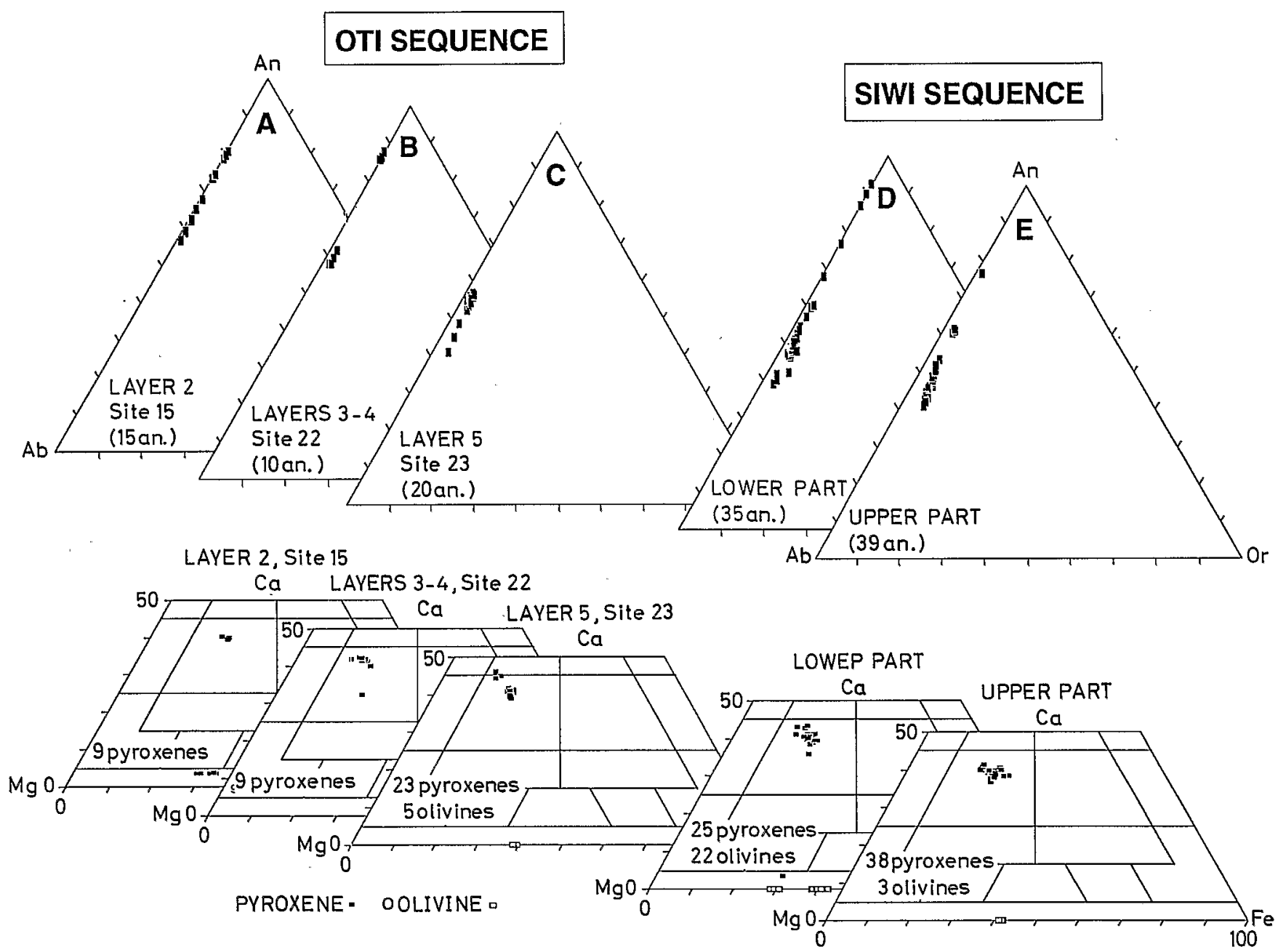

Fig. 6. Or-Ab-An diagram for plagioclases and $\mathrm{Ca}-\mathrm{Mg}-\mathrm{Fe}$ diagram for pyroxenes 
Table 2. Averages of glass compositions from microprobe data, calculated following the peaks observed Fig. 9

\begin{tabular}{|c|c|c|c|c|c|c|c|c|c|c|c|}
\hline & \multicolumn{4}{|c|}{ OTI ignimbrites } & \multicolumn{7}{|c|}{ Averages of glass compositions } \\
\hline & $\mathrm{BA}$ & & A1 & & $\mathrm{A} 2$ & & A3 & & $\mathrm{AA}$ & & $\mathrm{D}$ \\
\hline \multirow[t]{2}{*}{ No. an. } & 6 & & 21 & & 15 & & 18 & & 12 & & 2 \\
\hline & $\cdot$ & sd & & sd & & sd & & sd & & sd & \\
\hline $\mathrm{SiO}_{2}$ & 54.40 & 0.24 & 56.47 & 0.29 & 58.50 & 0.28 & 60.44 & 0.26 & 62.36 & 0.26 & 68.46 \\
\hline $\mathrm{TiO}_{2}$ & 1.04 & 0.18 & 0.81 & 0.16 & 0.80 & 0.12 & 0.78 & 0.05 & 0.73 & 0.19 & 0.68 \\
\hline $\mathrm{Al}_{2} \mathrm{O}_{3}$ & 15.09 & 1.12 & 16.03 & 0.60 & 16.16 & 0.83 & 15.74 & 0.33 & 15.93 & 1.74 & 13.14 \\
\hline $\mathrm{FeO}^{*}$ & 10.61 & 1.35 & 8.54 & 0.80 & 7.72 & 0.89 & 7.24 & 0.47 & 6.14 & 1.65 & 4.34 \\
\hline $\mathrm{MnO}$ & 0.20 & 0.07 & 0.20 & 0.07 & 0.15 & 0.07 & 0.19 & 0.09 & 0.16 & 0.09 . & 0.06 \\
\hline $\mathrm{MgO}$ & 4.00 & 0.61 & 3.28 & 0.44 & 2.60 & 0.43 & 2.02 & 0.24 & 1.35 & 0.52 & 0.32 \\
\hline $\mathrm{CaO}$ & 7.87 & 0.72 & 7.07 & 0.79 & 6.13 & 0.53 & 4.79 & 0.62 & 3.82 & 0.67 & 1.45 \\
\hline $\mathrm{Na}_{2} \mathrm{O}$ & 3.73 & 0.15 & 3.85 & 0.22 & 4.01 & 0.38 & 4.14 & 0.40 & 4.44 & 0.99 & 2.79 \\
\hline $\mathrm{K}_{2} \mathrm{O}$ & 1.96 & 0.39 & 2.46 & 0.44 & 2.85 & 0.35 & 3.87 & 0.87 & 4.25 & 1.15 & 7.01 \\
\hline \multirow[t]{4}{*}{$\mathrm{Cr}_{2} \mathrm{O}_{3}$} & 0.03 & 0.03 & 0.03 & 0.04 & 0.02 & 0.04 & 0.03 & 0.05 & 0.03 & 0.04 & 0.00 \\
\hline & 98.92 & 1.04 & 98.74 & 0.51 & 98.94 & 0.62 & 99.24 & 0.57 & 99.21 & 0.52 & 98.23 \\
\hline & \multicolumn{4}{|c|}{ Siwi ignimbrites } & \multicolumn{7}{|c|}{ Averages of glass compositions } \\
\hline & BA & & A & & AA & & $\mathrm{D}$ & & & & \\
\hline \multirow[t]{2}{*}{ No. an. } & 6 & & 12 & & 47 & & 6 & & & & \\
\hline & & sd & & sd & & sd & & $\mathrm{sd}$ & & & \\
\hline $\mathrm{SiO}_{2}$ & 55.63 & 0.30 & 57.56 & 0.28 & 61.54 & 0.32 & 64.40 & 0.22 & \multicolumn{3}{|l|}{$\mathrm{BA}=$} \\
\hline $\mathrm{TiO}_{2}$ & 0.85 & 0.15 & 0.82 & 0.11 & 0.83 & 0.13 & 0.74 & 0.10 & \multicolumn{3}{|c|}{ Basaltic Andesite } \\
\hline $\mathrm{Al}_{2} \mathrm{O}_{3}$ & 15.46 & 0.47 & 15.73 & 1.01 & 15.74 & 0.91 & 16.11 & 0.67 & \multicolumn{3}{|c|}{$A=$} \\
\hline $\mathrm{FeO}^{*}$ & 9.14 & 1.13 & 8.31 & 0.86 & 6.81 & 0.96 & 4.69 & 1.04 & \multicolumn{3}{|c|}{ Andesite } \\
\hline $\mathrm{MnO}$ & 0.22 & 0.11 & 0.21 & 0.08 & 0.18 & 0.07 & 0.14 & 0.09 & \multicolumn{3}{|c|}{$\mathrm{AA}=$} \\
\hline $\mathrm{MgO}$ & 3.17 & 0.46 & 2.74 & 0.20 & 1.72 & 0.41 & 1.04 & 0.34 & \multicolumn{3}{|c|}{ Acid Andesit } \\
\hline $\mathrm{CaO}$ & 6.33 & 1.10 & 5.82 & 0.31 & 4.14 & 0.53 & 3.21 & 0.31 & \multicolumn{3}{|c|}{$\mathrm{D}=$} \\
\hline $\mathrm{Na}_{2} \mathrm{O}$ & 3.69 & 0.46 & 4.21 & 0.51 & 4.07 & 0.68 & 4.14 & 0.97 & \multicolumn{2}{|c|}{ Dacite } & \\
\hline $\mathrm{K}_{2} \mathrm{O}$ & 2.38 & 0.76 & 2.75 & 0.48 & 3.99 & 0.58 & 4.14 & 0.91 & & & \\
\hline \multirow[t]{2}{*}{$\mathrm{Cr}_{2} \mathrm{O}_{3}$} & 0.06 & 0.05 & 0.03 & 0.03 & 0.01 & 0.02 & 0.07 & 0.08 & & & \\
\hline & 96.93 & 1.18 & 98.19 & 1.50 & 99.04 & 1.07 & 98.68 & 1.15 & & & \\
\hline
\end{tabular}

analyses at An 62 and one at An 77, Fig. 6e; olivine; Fo 58-60). Within the whole sequence, analyses from cores of clinopyroxene phenocrysts do not show large compositional variations (Fig. 6).

\section{Interpretation of data}

\section{Eruptive dynamisms}

In both sequences, the lower deposits (layers 2 and 3 for the OTI sequence, layer 1 for the Siwi sequence, Fig. 3) have phreatomagmatic characteristics, as demonstrated by quenched juvenile clasts, cauliflower bombs, surge features, coated lapilli, and indurated or muddy matrix. Moreover, the presence of palagonite within the matrix of the ashy deposits observed at the base of site 16 (layer 2) suggests that these products emplaced in a subaqueous environment. When the OTI erupted from the ETV volcano in the east, the present shoreline at site 16 probably corresponded to the low western slope of this edifice, near sea-level, as also suggested by raised limestones in the northern part of the island (Fig. 1a).

For the upper deposits, those from the Siwi sequence are easily interpreted, since the spatial lithologic relationships at site 5 (Fig. 3) and distinct textures from base to top represent a classical facies model from an ignimbrite unit. This is not the case for the OTI. The volcanologic significance of the main flow deposits at site 23 (layer 5 ) may be deduced from the following characteristics: (1) rare accidental clasts; (2) large juvenile fragments ( $\max 1 \mathrm{~m}$ ), commonly breadcrust bombs (up to $40 \%$ of the volume); (3) massive indurated or poorly welded beds without stratification; and (4) matrix consisting of lapilli that range from pumiceous to scoria, and sparse coarse ash. This dense material is too heavy to have been transported far from the source, and we suggest an origin from an eruptive column, fines depleted during collapse, in a process similar to that producing the lag-fall breccia (Druitt and Sparks 1982; Walker 1985). The OTI deposits at Lenambtaim Point (Fig. 4) resemble the Acatlan and Campanian poorly vesiculated bomb deposits (Wright and Walker 1981; Rosi et al. 1983) and characterize the proximal deposits of a typical ignimbrite eruption (Sparks et al. 1973; Sparks and Wilson 1976; Sparks and Walker 1977) dominated by a complex flux regime. Their presence is of value in locating an ignimbrite source vent to the east, not far off the coast.

The large areal extent of the OTI pyroclastic series up to the western coast of the island also suggests that the flat central part of Tanna island is a tuff ring probably related to a caldera or an enlarged vent. The incorporation of accidental clasts from the basal shield volcano to the pyroclastic deposits, especially in layers 5 , is an additional argument in favour of collapse of the roof into the reservoir and/or enlargement of the vent. 

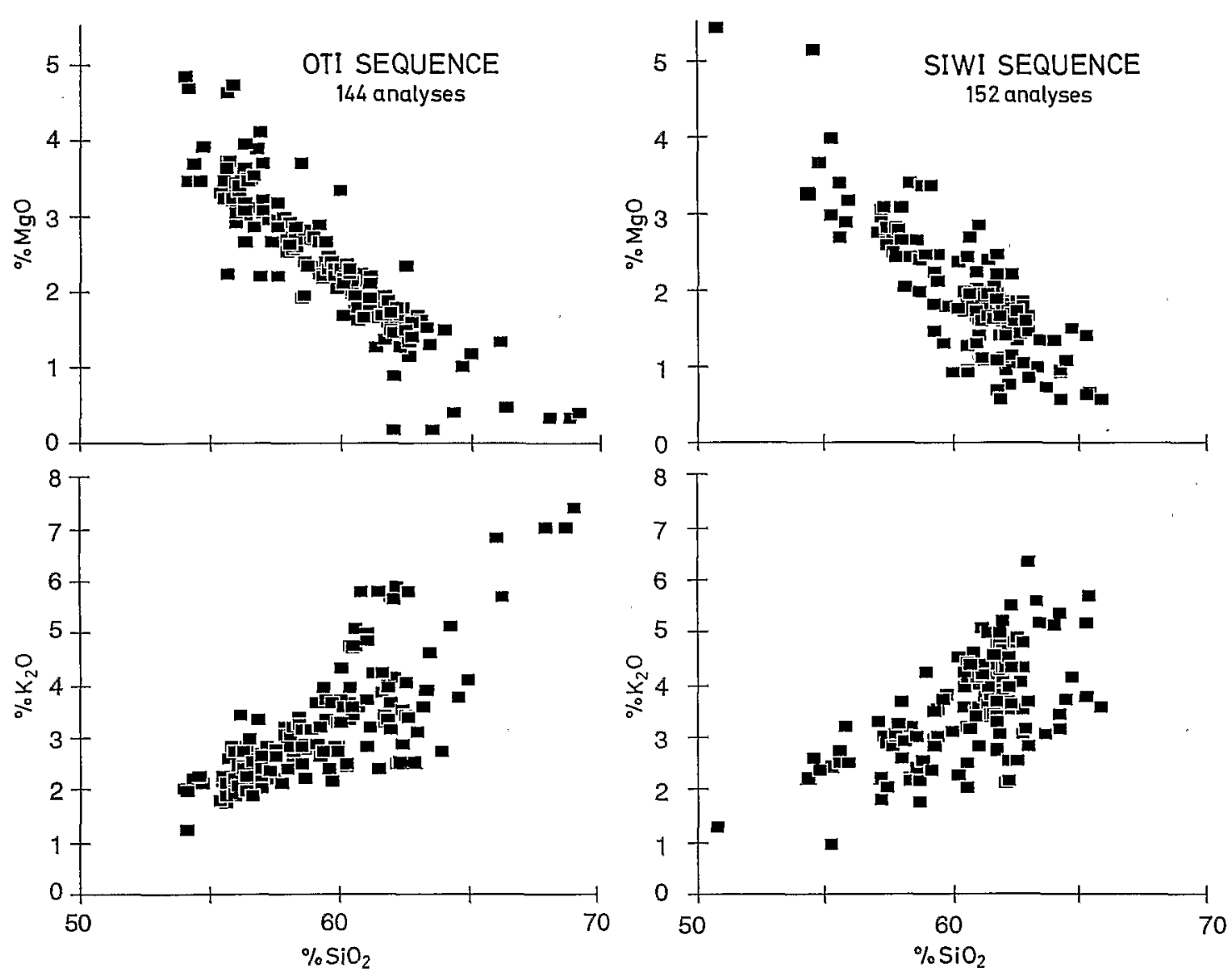

Fig. 7. $\mathrm{MgO}$ and $\mathrm{K}_{2} \mathrm{O}$ versus $\mathrm{SiO}_{2}$ diagrams of the analysed glasses from the OTI and Siwi sequences

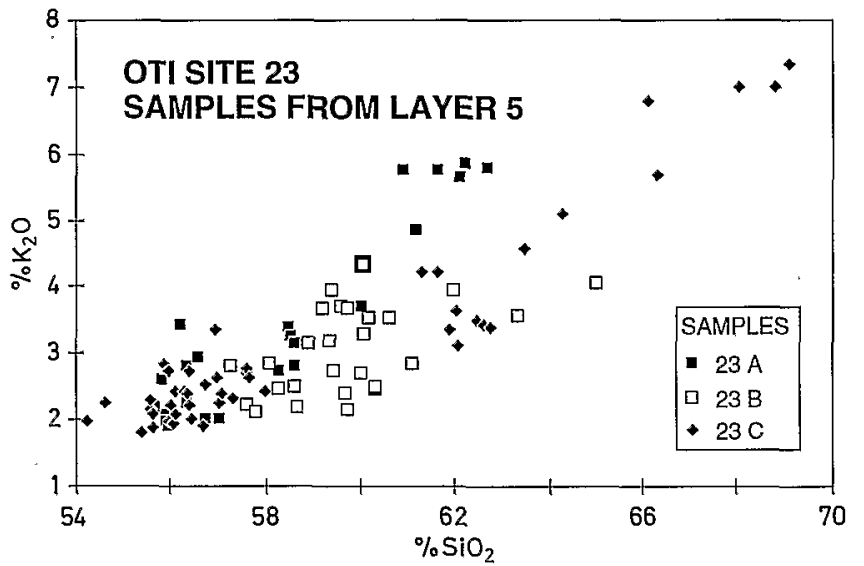

Fig. 8. $\mathrm{K}_{2} \mathrm{O}-\mathrm{SiO}_{2}$ diagram for the analysed glasses within three juvenile clasts from the OTI ignimbrite at site 23

\section{Petrologic significance of the ignimbrites}

A question raised by the large compositional range for the whole-rock samples and vitric components, is to know if these compositions were produced by mixing, or by various degrees of differentiation of the same parental magma. The absence of features typical of magma mixing (abnormal mineralogical associations, reverse zonings, disequilibrium features) argues in fa- vour of the second process. In order to address this question and to constrain the petrologic and volcanologic significance of these pyroclastics, we have tested both mixing and crystal fractionation models to wholerock and glass compositions, using the Igpet Mac program by Carr (1991).

Prior to discussing the results reported in Table 3, we need to examine an important question concerning geochemical interpretations of the New Hebrides volcanoes. As mentioned earlier, at first sight, crystal fractionation seems responsible for the whole-rock geochemistry of samples reported in Table 1 . Nevertheless, considering some ratios of incompatible elements, large variations occur between samples having a similar degree of differentiation (e.g. $\mathrm{Ba} / \mathrm{Rb}=24$ in TA 9B versus 13 in $\mathrm{TA} 5 \mathrm{~A}$, and $\mathrm{Rb} / \mathrm{La}=2.8$ in $\mathrm{TA} 16$ versus 4.2 in TA 23 C). Such variations, which seem to preclude a crystal-fractionation model as well as a magmamixing model, are due to the anomalous behaviour of a few incompatible elements in the New Hebrides volcanic arc, a problem already stressed by many authors. Along the arc, the distribution of $\mathrm{K}$ (and other incompatible elements, specially $\mathrm{Ba}$ and $\mathrm{La}$ ) reveals important variations which are not well understood (Gorton 1977; Roca 1978; MacFarlane et al. 1988). These variations even occur in a sole volcano as demonstrated by 'slight but significant differences in $\mathrm{K} / \mathrm{Rb}$ ratios' in compositions of lavas from the small Karua cone 


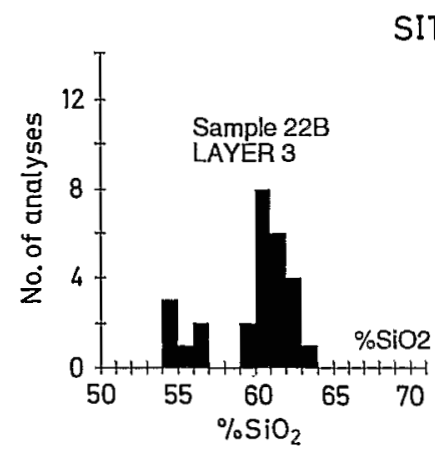

SITE 22
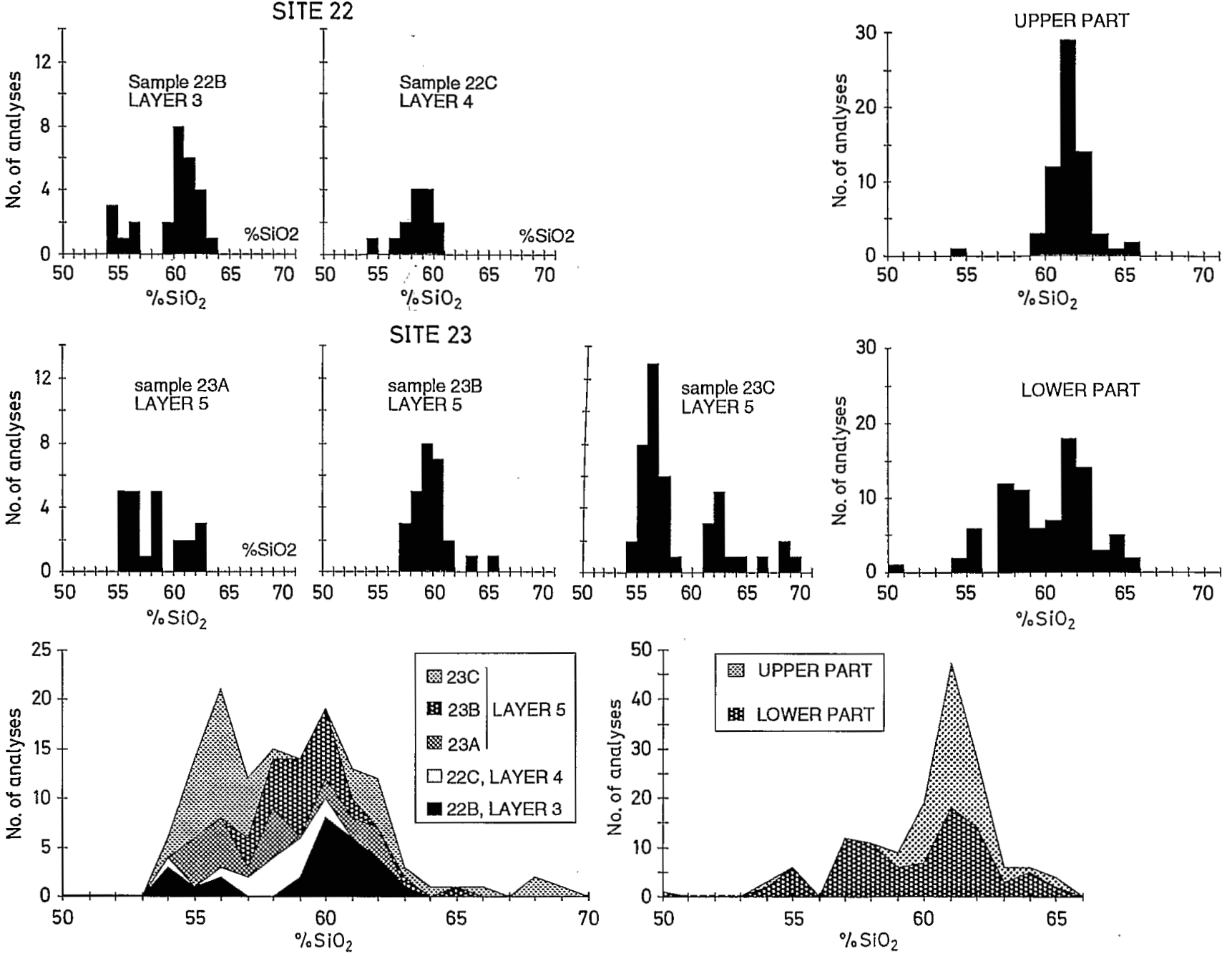

Fig. 9. Frequency histogram for microprobe glass compositions in juvenile clasts from the OTI and Siwi ignimbrite sequences. Samples and whole OTI and Siwi sequences Class 55 $=55.00-55.99$

(Crawford et al. 1988), and by concomitant High-K and Low-K volcanic series at Ambrym volcano (Robin et al. 1991; Picard et al. in press). Source effects and mantle metasomatism are generally proposed to explain these variations. In addition, Eggins (1989) showed that the geochemistry of Aoba volcano in central New Hebrides was controlled by two sources or more. Thus, in the following section, crystal fractionation and mixing models will be based only on major elements and on highly to moderately compatible trace elements.

Wholerocks. Two main types of juvenile blocks have been analysed: (1) blocks constituted by welded shards and fiammae of different compositions (e.g. samples 22 $\mathrm{B}$ and $23 \mathrm{C}$; Fig. 9); and (2) blocks with near-homogeneous composition (e.g. $23 \mathrm{~B}$ ).

In a few cases, tests of mixing applied to the nearhomogeneous samples indicate that these samples may result from the homogenization of the heterogeneous ones. Nevertheless, such successful tests are rare (lines 1 and 2, Table 3a) and although the sum of the squares of residuals for major elements is less than 1, high residuals for most trace element tests, especially compatible elements such as $\mathrm{Cr}, \mathrm{Co}, \mathrm{Ni}$, Sc (i.e. elements which are not influenced by source effects), show that mixing is unlikely to have produced the different compositions (see tests 3-8 as examples).

Glasses. The compositional gaps in many samples (Fig. 9) strongly suggest that the dominant process in producing the diverse glass compositions is crystal fractionation, and that these compositions are representative of various layers in a zoned magma chamber. The same mixing tests were applied to the average glass compositions from Table 2. As the sum of squares of residuals, calculated over only nine elements (major elements except $\mathrm{P}_{2} \mathrm{O}_{5}$ ), ranges from 0.2 to 4 , we conclude that mixing cannot explain the data. On the other hand, crystal fractionating gives excellent results, from basaltic andesite BA to andesite A3, through intermediate andesites $\mathrm{A} 1$ and $\mathrm{A} 2$ (sigma $\mathrm{r} 2=0.01-0.15$; Table $3 \mathrm{C}$ ). These results are compatible with the modal composition and the mineralogical evolution of the rocks. 
Table 3. Results of mixing and crystal fractionation tests

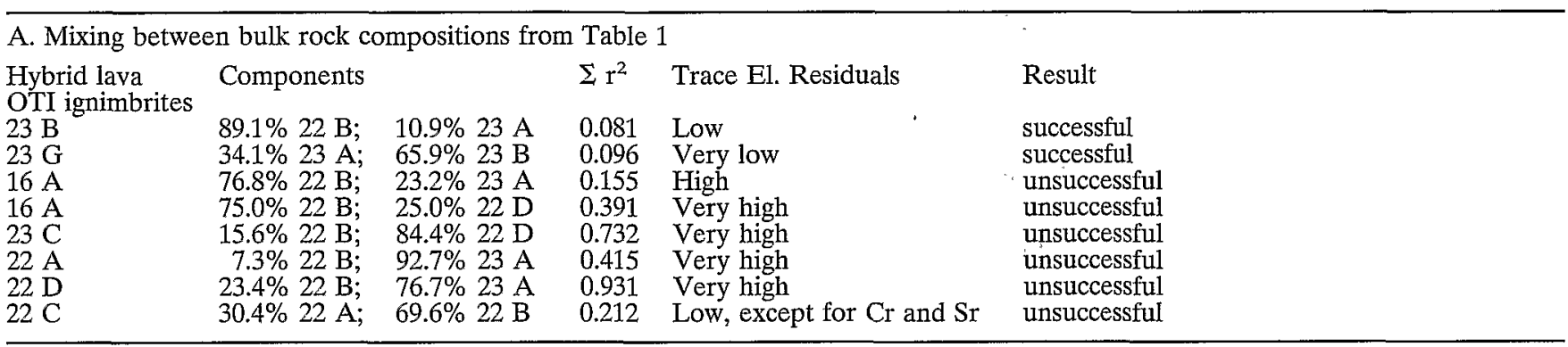

B. Mixing calculations with average glass compositions from Table 2

$\begin{array}{lllll}\text { Hybrid lava } & \text { Components } & & \Sigma \mathrm{r}^{2} & \text { Result } \\ \text { OTI ignimbrites } & & & \\ \text { A1 } & 38.9 \% \text { BA; } & 61.1 \% \text { A2 } & 0.231 & \text { unsuccessful } \\ \text { A1 } & 59.1 \% \text { BA; } & 40.9 \% \text { A3 } & 0.921 & \text { unsuccessful } \\ \text { A1 } & 68.7 \% \text { BA; } & 31.3 \% \text { AA } & 0.887 & \text { unsuccessful } \\ \text { A2 } & 69.0 \% \text { BA; } & 31.0 \% \text { D } & 2.566 & \text { unsuccessful } \\ \text { A2 } & 47.1 \% \text { BA; } & 52.9 \% \text { AA } & 0.665 & \text { unsuccessful } \\ \text { A1 } & 82.1 \% \text { BA; } & 17.9 \% \text { D } & 1.733 & \text { unsuccessful } \\ \text { A3 } & 53.8 \% \text { BA; } & 46.2 \% \text { 23 D } & 1.871 & \text { unsuccessful } \\ \text { A3 } & 66.0 \% \text { A1; } & 34.0 \% \text { D } & 0.790 & \text { unsuccessful } \\ \text { AA } & 39.6 \% \text { BA; } & 60.4 \% \text { D } & 4.005 & \text { unsuccessul } \\ \text { AA } & 49.7 \% \text { A1; } & 50.3 \% \text { D } & 2.469 & \\ \text { AA } & 59.6 \% \text { A2; } & 40.4 \% \text { D } & 1.537 & \text { unsuccessful } \\ \text { Siwi ignimbrites } & & & & \text { unsuccessful } \\ \text { A } & 69.5 \% \text { BA; } & 30.5 \% \text { AA } & 0.224 & \text { unsuccessful } \\ \text { AA } & 45.9 \% \text { A; } & 54.1 \% \text { D } & 0.545 & \end{array}$

C. Crystal fractionation models between average glass compositions OTI ignimbrites (Glass compositions from Table 2A)

$\begin{array}{llllclll}\text { Parent } & \text { \% Daughter } & \text { \% olivine } & \text { \% pyr. } & \text { \% plag. } & \begin{array}{l}\text { \% Fe-Ti } \\ \text { oxides }\end{array} & \Sigma \mathbf{r}^{2} & \text { Results } \\ \text { BA } & 85.6 \% \text { A1 } & 0.5 & 6.4 & 4.4 & 3.1 & 0.085 & \text { successful } \\ \text { A1 } & 84.3 \% \text { A2 } & 1.1 & 4.6 & 8.4 & 1.5 & 0.014 & \text { successful } \\ \text { A2 } & 80.7 \% \text { A3 } & 1.2 & 4.2 & 12.8 & 1.2 & 0.159 & \text { successful } \\ \text { A3 } & 88.9 \% \text { AA } & 0.5 & 3.9 & 5.0 & 1.4 & 0.010 & \text { successful }\end{array}$

$\mathrm{AA} \rightarrow \mathrm{D}$ Impossibility with the determined minerals (propably, fractionation of Na-rich non-analysed feldspar and apatite). Siwi ignimbrites (Glass compositions from Table $2 B$ )

\begin{tabular}{llllclll} 
Parent & \% Daughter & \% olivine & \% pyr. & \% plag. & $\begin{array}{l}\text { \% Fe-Ti } \\
\text { oxides }\end{array}$ & $\mathbf{r}^{2}$ & Result \\
BA & $90 \%$ A & 1.0 & 3.1 & 4.6 & 1.3 & 0.074 & successful \\
A & $73.9 \%$ AA & & 8.2 & 15.0 & 3.0 & 0.310 & successful \\
AA & $87.9 \%$ D & & 4.4 & 5.0 & 2.7 & 0.129 & successful \\
\hline
\end{tabular}

Only the transition from $\mathrm{SiO}_{2}=61-62$ to $68 \%$ (average compositions of AA and D, Table 2) is not well reproduced by this process, probably due to involvement of minor phases ( $\mathrm{Na}$-rich plagioclase and apatite?) during this late stage of fractionation. In addition to the general crystal fractionation process, some limited mixing at the thin section scale can occur, as suggested by a few analyses plotting between the peaks (Fig. 9).

Results for the Siwi ignimbrite are comparable: Tables $3 \mathrm{~b}$ and $\mathrm{c}$ show that mixing calculations give poor results whereas fractionation models (sigma $\mathrm{r} 2=0.07-$ 0.31 ) fit well, in agreement with the modal mineralogy and the whole-rock and glass compositions throughout the sequence.

\section{Discussion - Inferred model of eruption}

A wide range of compositions across a single ignimbrite unit is a well-known although uncommon phenomenon. Compositional changes in some studied ignimbrites (Lipman et al. 1966; Schmincke 1976; Gardeweg and Ramirez 1987) are generally restricted to dacitic and rhyolitic magmas, and are believed to represent uppermost layers of large zoned magma chambers. Wright and Walker (1981) report compositions ranging from $60-73 \% \mathrm{SiO}_{2}$ for an ignimbrite from Mexico. To our knowledge, published examples showing a comparable range of compositions to that of Tanna's ignimbrites (basalt to dacite/rhyolite) invoke discontinuous compositions and triggering of an eruption by introduction of deep-derived, volumetrically subordinate mafic magma into a shallow voluminous reser- 
voir of evolved rhyolitic magma (Sparks et al. 1977). Based on our detailed sampling and-chemical analyses, in the case of the OTI, we can assert that the dominant composition in the magmatic reservoir is mafic (basaltic andesite) and that the magmas erupted are essentially andesitic (from 53 to $63 \% \mathrm{SiO}_{2}$ ). Andesitic composition is also dominant in the Siwi sequence, but a compositional difference exists between the lower and upper members: the lower products are representative of the whole andesitic domain whereas the upper ones are confined to acidic andesites.

Because the overall composition of most of the OTI and Siwi products is andesitic, the mechanics of the eruption must differ from that of a potentially self-explosive acidic magma (dacite or rhyolite) for which gas overpressure may be sufficient in producing eruption. Since our results preclude a mixing process between a deep mafic and a silicic magma, a hypothesis invoking triggering of the eruption by introduction of basalt into a differentiated magma chamber must also be rejected. Thus, the generalized frequency histograms of Fig. 9 may give a quantitative representation of the zoned chamber just before the explosive events, and we conclude that each of these two successions of phreatomagmatic products and ignimbrites resulted from rapid emptying of a large magma body having a strong compositional gradient imposed by crystal fractionation.

In both cases, as a primary consideration, we note an intimate association between lower phreatomagmatic deposits and upper ignimbrite deposits, sustained by field data and petrologic observations and data. Therefore, a model of eruption must take into account five main considerations: (1) phreatomagmatic processes during the earlier stages of eruption; (2) welded textures indicating a hot state of emplacement in a subaerial environment for the main deposits; (3) induration and glassy blocks in the upper pumice flow deposits of the OTI, that also show magma-water interaction, probably to a lesser extent than for the lower ash flows; (4) simultaneous eruption of mafic and intermediate magmas at all stages of the OTI sequence and at the beginning of the Siwi sequence; and (5) homogenization of the composition as the eruption of the Siwi sequence developed.

Mafic magmas are considered unable to give large explosive eruptions without intervention of externally derived water. The implication of water in the development of an eruption producing small-scale andesitic pyroclastic flows has been reported in some places, such as Coseguina (Self et al. 1989). At Tambora, voluminous Plinian pumice falls, surges and pyroclastic flows were generated during the climactic eruption, after a phreatomagmatic ash-fall event which lasted five days (Sigurdsson and Carey 1989). At Tanna, the phreatomagmatic features of the lower deposits suggest that introduction of external water at the top of the magmatic column may have triggered eruptions, and the presence of large-sized dense vitric clasts indicates high-energy eruptions due to abundant water. A mechanism of eruption similar to that proposed by Rocher and Westercamp (1989) for the Salazie Ignim- brite in La Reunion island is suggested for starting the pyroclastic event: the head of the zoned magma chamber may be cooled to a plug or develop important chilled margins owing to infiltration of external water, perhaps continuously over a long time interval. Further introduction of water into the upper magmatic column (due to a seismic event?), produced overpressure at the top of the chamber, eventually producing an eruption which exceeded the tensile strength of the rock pile, and leading to the massive overflow of hydrovolcanic products, as a mixture of gas, dense vitric and vesiculated blocks and xenoliths. Opening of the vent induces depressurization and convection in the magma chamber, as indicated by vesiculation and associated heterogeneous magma.

Glass compositions in samples from sites 22-23 represent liquids from differentiated layers in the magmatic chamber just before the eruption. During the eruption, these layers disintegrated and droplets of various compositions were mechanically mixed, but usually without homogenization of the resulting product. Probably, water also catalysed incipient magmatic explosions by quench fracturing fragile vesicle walls of the vesiculating magma, allowing rapid decompression and expansion (Cas and Wright 1987). Water was also present in sufficient volume to induce rapid cooling of the flows. Somewhat different eruptive sequences to the OTI may be observed in the case of interaction between magma and water, as for the 'Minoan Tuff' described by Heiken and McCoy (1984) at Santorini.

To lead to the turbulent convective regime necessary to produce the general heterogeneity in composition of the OTI and lower Siwi deposits, the magma chamber is unlikely to have been thick, with strong vertical development. The whole petrologic evolution through the Siwi sequence, from heterogeneous compositions in the lower part to a more homogeneous composition in the upper member, may be explained by a two-step eruption: first, rapid convection below the vent produced the eruption of the former heterogeneous magma; then, vesiculation extends laterally, provoking the eruption of the homogeneous magma from the upper 'acid' layers of the magma chamber. This was probably accompanied by an enlargement of the vents and collapse of the roof into the magmatic reservoir.

Acknowledgements. This work was financially supported by ORSTOM UR $1 F$ and the French Foreign Affairs Ministry (MAE). We thank C Mortimer and C Reichenfeld, respectively Director of the Department of Geology, Mines \& Rural Water Supply of Vanuatu, and Director of the ORSTOM Centre of Port-Vila in 1991. The authors are also indebted to Charley Douglas for his help during the fieldwork and to RV Alis's captain Le Boulch and his crew. Marcel Bohn and Joseph Cotten are deeply thanked for the geochemical analyses and Dr Tony Crawford for revision and comment on a first version.

\section{References}

Bice DC (1985) Quaternary volcanic stratigraphy of Managua, Nicaragua: correlation and source assignment for multiple overlapping plinian deposits. Geol Soc Am Bull 96:553-566 
Carney JN, McFarlane A (1979) Geology of Tanna, Anneytum, Futuna and Aniwa. New Hebrides Geol Surv Reg Rep, Port Vila, $79 \mathrm{pp}$

Carr MJ (1991) Igpet Mac program. Terra Softa Inc, Somerset, NJ, USA

Cas RAF, Wright JV (1987) Volcanic successions: modern and ancient. A geological approach to processes, products and successions. Allen \& Unwin, London, $528 \mathrm{pp}$

Coulon C, Maury RC (1981) Petrology of Tholeiitic lavas from Tanna Island (New Hebrides): Importance of cumulative processes in Island Arc Magmatism. Bull Volcanol 44-4:662680

Crawford AJ, Greene HG, Exon NF (1988) Geology, petrology and geochemistry of submarine volcanoes around Epi island, New Hebrides island arc. In: Greene HG and Wong FL (eds) Geology and offshore resources of Pacific island arcs - Vanuatu region. Circum-Pacific Council for Energy and Mineral Resources Earth Science Series 8, Houston, Texas: 301-327

Druitt TH, Sparks RSJ (1982) A proximal ignimbrite breccia facies on Santorini, Greece. J Volcanol Geotherm Res 13:147171

Dugas F, Carney JN, Cassignol C, Jezek PA, Monzier M (1976) Dredged rocks along a cross-section in the Southern New Hebrides Island Arc and their bearing on the age of the arc. In: Geodynamics in South-West Pacific. Technip Ed. Paris: 105116

Eggins SM (1989) The origin of primitive ocean island and island arc basalts. PhD thesis. University of Tasmania, $402 \mathrm{pp}$

Gardeweg M, Ramirez CF (1987) La Pacana caldera and the Atana Ignimbrite. A major ash-flow and resurgent complex in the Andes of northern Chile. Bull Volcanol 49:547-566

Gorton MP (1977) The geochemistry and origin of Quaternary in the New Hebrides. Geochim Cosmochim Acta 41:1257-1270

Heiken G, McCoy F (1984) Caldera development during the Minoan Eruptions. Thira, Cyclades, Greece. J Geophys Res 89:8441-8462

Lipman PW, Christiansen RL, O'Connor JT (1966) A compositionally zoned ash-flow sheet in southern Nevada. US Geol Surv Prof Pap 524-F:1-47

McFarlane A, Carney JN, Crawford AJ, Greene HG (1988) Vanuatu - A review of the onshore geology. In: Greene $\mathrm{HG}$ and Wong FL (eds) Geology and offshore resources of Pacific island arcs - Vanuatu region, Circum-Pacific Council for Energy and Mineral Resources Earth Science Series 8, Houston, Texas: 45-91

Monzier M, Robin C, Eissen JP, Picard C (1991) Découverte d'un large anneau de tufs basaltiques associé à la formation de la caldéra d'Ambrym (Vanuatu, SW Pacifique). Comptes Rendus Ac Sc Paris 2, 312:1319-1326

Nairn A, Scott BJ, Giggenbach WF (1988) Yasur volcano investigations, Vanuatu, Sept 1988. New Zealand Geol Surv Rep G $134: 74 \mathrm{pp}$

Picard C, Monzier M, Eissen JP, Robin C (in press) Concomitant evolution of tectonic environment and magma geochemistry, Ambrym volcano (Vanuatu - New Hebrides arc). J Geol Soc London, sp issue of the meeting Volcanism associated with extension at consuming plate margins JL Smellie (ed)
Robin C, Monzier M, Eissen JP, Picard C, Camus G (1991) Coexistence de lignées $\mathrm{HK}$ and $\mathrm{MK}$ dans les pyroclastites associées à la caldéra d'Ambrym (Vanuatu, Arc des Novuelles Hébrides). Comptes Rendus Ac Sc Paris 2, 313:1425-1432

Robin C, Eisen JP, Monzier M (1993) Giant tuff cone and 12 kmwide associated caldera at Ambrym volcano, New Hebrides Arc. J Volcanol Geotherm Res 55:225-238

Roca JL (1978) Contribution à l'étude pétrologique et structurale des Nouvelles Hébrides. Thesis Univ Sciences et Techniques du Languedoc, Montpellier $157 \mathrm{pp}$

Rocher P, Westercamp D (1989) The Salazie cirque ignimbrite (Piton des neiges Volcano, Reunion Island): Chronostratigraphy, description and significance of lithic fragments and eruptive mechanisms. J Volcanol Geotherm Res 36:177-191

Rosi M, Sbrana A, Principe C (1983) The Phlegraean fields: structural evolution, volcanic history, and eruptive mechanisms. J Volcanol Geotherm Res 17:273-288

Schmincke HU (1976) Geology. of the Canary islands. In: Kunkel G (ed) Biogeography and ecology in the Canary Islands. W Junk, The Hauge:67-184

Self S, Rampino MR, Carr MJ (1989) A reappraisal of the 1835 eruption of Cosigüina and its atmospheric impact. Bull Volcanol 52:57-65

Sigurdsson H, Carey S (1989) Plinian and co-ignimbrite tephra fall from the 1815 eruption of Tambora volcano. Bull Volcanol 51:243-270

Sparks RSJ, Walker GPL (1977) The significance of vitric air-fall ashes associated with crystal-enriched ignimbrites. J Volcanol Geotherm Res 2:329-341

Sparks RSJ, Wilson L (1976) A model for the formation of ignimbrite by gravitational column collapse. J Geol Soc London 132:441-451

Sparks RSJ, Self S, Walker GPL (1973) Products of ignimbrite eruption. Geology 1:115-118

Sparks RSJ, Sigurdsson H, Wilson L (1977) Magma mixing: a mechanism for triggering acid explosive eruptions. Nature 267:315-318

Taylor GA (1956) Review of the volcanic activity in the Territory of Papua-New Guinea, the Solomon and New Hebrides islands, 1951-1953. Bull Volcanol 18:25-37

Walker GPL (1985) Origin of coarse lithic breccias near ignimbrite source vents. J Volcanol Geotherm Res 25:157-171

Williams CE, Curtis R (1964) The eruption of Lopevi Volcano, New Hebrides, July 1960.'Bull Volcanol 27:423-433

Williams CEF, Warden AJ (1964) Progress report of the Geological Survey for 1959-1962. New Hebrides Geol Surv Rep, Port Vila, New Hebrides, 75 pp

Williams H, McBirney AR (1979) Volcanology. Freeman, Cooper, San Francisco, 391 pp

Williams SN (1983) Plinian airfall deposits of basaltic composition. Geology 11:211-214

Wright JV, Walker GPL (1981) Eruption, transport and deposition of ignimbrite: a case study from Mexico. J Volcanol Geotherm Res 9:111-131

Editorial responsibility: T. $\mathrm{Mi}$ 